THE

\title{
GEOLOGICAL FORMATIONS
}

\author{
CROSSED BY THE
}

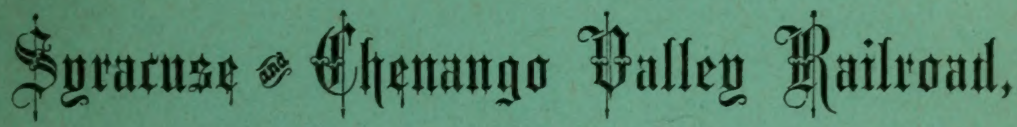

TOGETHER WITH $\Lambda$ SKETCH OF THE

HYDROGRAPHY AND VALLEY FORMATIONS

OF

Madison and Onondaga Counties.

A THESIS FOR THE DEGREE OF Ph. D.

LUCIEN M. UNDERWOOD.

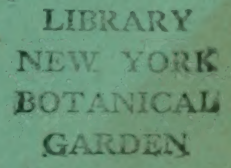

SYRACUSE, N. Y.

STANDARD PUBLISHING COMPANY.

1879. 


$$
\begin{aligned}
& 146 \\
& .123 \\
& \text { थ. } 53 \\
& c .2
\end{aligned}
$$




\title{
THE GEOLOGICAL FORMATIONS
}

\author{
CROSSED BY THE
}

\section{Syracuse Chenango Vialley Rु. Rु.}

TOGETHER WITH A

SKETCH OF THE HYDROGRAPHY VALLEY FORMATIONS

OF

MADISON AND ONONDAGA COUNTIES.

\section{SYNOPSIS OF THESIS.}

I. GEOLOGICAL FORMATIONS.

A. SALINA.

1. Outereps.

2. Neighboring localities of same formation.

3 . Rocks and minerals.

4. Fossil remains.

5. Economical products.

B. Lower HElderberg.

1. Outcrops.

2. Neighboring localities of same formation.

3. Rocks and minerals.

4. Fossil remains.

5. Economical products.

C. Corniferous.

1. Outerops.

2. Neighboring localities of same formation.

3. Rocks.

4. Fossil remains.

5. Economical products.

D. HAMILTON.

1. Divisions.

a. Marcellus Shale.

b. Hamilton beds, proper.

c. Genesee Shale. 
2. Outcrops.
a. Marcellus.
b. Hamilton proper.
c. Genesee.

3. Neighboring localities of same formation.

a. Marcellus Shale.

b. Hamilton proper.

c. Tully Limestone.

d. Genesee Shale.

4. Rocks.

5. Fossil remains.

6. Economical products.

E. DRIFT.
1. Nature of deposits.
2. Origin of deposits.
3. Natural products, timber, etc.
4. Adaptability to agricultural products.
5. Economical products.

II. HYDROGRAPHY OF MADISON AND ONONDAGA COUNTIES.
A. Drainage.
1. St. Lawrence system.
2. Atlantic (Susquehanna) system.
B. Trend of watershed.
C. Waterfalls.
D. Lakes and ponds.
E. Mineral springs.
F. Effect of clearings on streams.

\section{VALLEY FORMATIONS OF MADISON AND ONONDAGA COUN'TIES.}

A. General trend of local valleys.

B. Similarity to formations elsewhere.

C. Former higher level of lakes; their probable future.

D. Theory of valley formation.

IV. TABLES AND LISTS. 


\section{GEOLOGY.}

The opening of a line of railroad always affords new opportunity for the study of local geology, by exposing to view the rock and drift formations on the line of the road and opening the way for the discovery of new fossils, peculiar forms of rock structure, and valuable building material. As the practical and economic value of local geology was long since demonstrated, it is evident that the opening of new roads throughout the country subserves other ends than that of mere transportation. Scientific investigation and careful study must follow such openings to bring out the most valuable results.

The Syracuse and Chenango Valley R. R. extending from Syracuse to Earlville, Madison County, passes through a fertile and thriving agricultural country, and one, not only diversified by beautiful scenery, but also marked by its variety of geological formations. In its short course of forty-three miles it passes over the formations from the Salina group in the Silurian to the Genesee Shale in Middle Devonian. Leaving Syracuse 395 feet above tide-water the road passes with gradual grade in an easterly direction to near Manlius Centre, through the valley or lowland that crosses central and western New York; then turning southeast with increasing grade, it cuts through the rocks of the Salina group a little north of Fayetteville, and successively crosses the water limestone of the Lower Helderberg and the Onondaga Limestone of the Corniferous between that place and Oran; south of Oran it reaches the Marcellus shale which continues to the tunnel on the west side of Cazenovia Lake. This tunnel is sixteen hundred feet long besides the approaches and cuts through the rocks of the Marcellus Shale at its western approach and through the true Hamilton beds in its eastern portion. The Hamilton proper continues to underlie the road-bed to the southern part of Madison County, yet few cuts are found as the drift deposit is generally deep; the "black shales" of the Genesee group commence in Lebanon and continue to the terminus of the road. The highest point of the road is near Georgetown, 1630 feet above the sea ; Earlville, the southern terminus, is 1077 feet.

Following are the formations arranged in order of occurrence as well as in order of time, for as we ride from syracuse to Earlville we pass up the geological scale from the older to the newer formations. The rocks are all of sedimentary origin so that each successive line of formation indicates the boundary line of the sea in the respective geological periods represented.

\section{A. SALINA GROUP.}

1. The outcrops of the rocks of the Salina group are found between Manlius Centre and Fayetteville. Just south of the railroad bridge crossing the Erie Canal are three cuts 1140,550, and 750 feet long respectively, separated by interruptions of 90 feet each. The rocks in the first are about 60 feet in thickness, and in the others from 15 to 20 feet. Another small bed occurs about twenty rods farther south, very shallow, but this is probably due to the fact that the grade is ascending and the road rises above the formation. Trending toward the east from the canal bridge is a high ridge through which these cuts are made, forming the southern boundary of the basin before alluded to which crosses Onondaga and Madison counties from east to west; on the west side of the railroad this same ridge trends towards the south, forming the eastern boundary of the basin of Limestone Creek. 
2, Rocks of the same formation may be found east in the towns of Lenox and Stockbridge, and west at Syracuse (Spruce Street, University Avenue and Adams Street, D. L. and W. R. R., near Oakwood, etc.), and Camillus (N. Y. C. R. R., Auburn Branch). By reference to a map it will be seen that all these places are in an east and west line a little above parallel $43^{\circ} \mathrm{N}$. Lat.

3. The rocks of this formation are mostly argillaceous shales or shaly limestones, usully of a light drab color, though sometimes darker and bluish or greenish. The upper beds approximate in appearance to the rocks of the succeeding water lime group, being for the most part impure hydraulic limestones. A portion of the beds consist of a calcareous rock filled with pores or cells, called by Eaton "Vermicular Limerock" from the resemblance of the pores to worm holes. These pores probably contained crystals at some time which are for the most part dissolved away, yet some are even now partly or wholly filled by crystalline mineral matter. This Vermicular rock is also found in Syracuse near Oakwood Cemetery, and on University Avenue, where it rises nearly to the surface. These forms of rock all contain sufficient calcium carbonate $\left(\mathrm{Ca} \mathrm{CO}_{3}\right.$ ) to effervesce with cold hydrochloric acid; of the ordinary shale about 20 per cent will dissolve in acid, while about 40 per cent of the vermicular and hydraulic limestones are soluble. The only mineral commonly found is gypsum $\left(\mathrm{Ca} \mathrm{SO}{ }_{4}\right)$ principally in its laminated form known as selenite; beautiful specimens may be found in the first of the rock cuts of this formation, some as transparent as the purest glass, some so mingled with earthy impurities, or worn by the dissolving action of water as to be only translucent or even opaque. Fibrous gypsum is found occasionally in very thin and fragile layers parallel to the planes of stratification, and it also occurs massive. Here as in other parts of Onondaga County, notably at Camillus, may be found what are known as "hopper shaped cavities and crystals ;" these cavities are the molds of crystals of common salt, which has the peculiarity of crystallizing in cubes which so unite by their edges as to form "hoppers;" the salt then dissolves away and leaves its imprint in a matrix. The "hopper shaped crystals" are denominated as pseudomorphs by the mineralogist; cavities or molds are first formed as above, and after the salt is dissolved away they are filled with other mineral matter which takes the peculiar form of the original crystals of salt. These imitations of form in the mineral kingdom are not uncommon among a large number of mineral species.

4. No fossils are found in these cuts and they are extremely rare in all parts of the Salina formation. It is generally held by geologists that the rocks of this period were formed in estuaries or enclosed portions of the sea containing water intensely salt and bitter, and consequently not supporting animal life. Perhaps a modern example of similar azoic water may be found in that of the Dead Sea.

\section{B. LOWER HELDERBERG.}

1. The outcrops of the Lower Helderberg are found between Fayetteville an Manlius; about one-half mile south of the former place occurs the first cut through the formation extending for 390 feet and after an interruption of 60 feet continuing 270 feet farther. The rocks here are cut through only about four feet in depth. Farther south occurs a deeper cut extending 840 feet with rock varying from 10 to 12 feet in thickness. A lime-kiln is situated at the southern terminus using rocks for burning similar to those in this cut, as well as those of the water-lime proper, which are obtained from quarries in the adjoining hills. Some 40 rods north of this lime-kiln beds are found about 15 feet thick extending for 600 feet along the track. The rock in this bed is much more laminated and shaly and consequently less valuable. Just north of Manlius station are found the last beds of this formation extending for 540 feet and nearly 25 feet thick. These beds are little cut by the 
railroad proper, but adjoining beds are quarried and the formation seems to extend extensively under the neighboring hill. The grade between the two places is 50 feet to the mile; the width of the formation as indicated by the outcrops is about two miles.

2. Rocks of the same formation occur between Syracuse and Jamesville (line of D. L. and W. R. R.); at Chittenango Falls forming the lower strata of the gorge below the falls, at Perryville Falls in a similar position, and in the towns of smithfield aud stockbridge, Madison County. The outcrop of the formation thus forms a narrow band extending across the two counties east and west for a short distance on either side of parallel $43^{\circ} \mathrm{N}$. Lat.

3. The rocks of the various cuts vary in appearance, texture, and composition. While all are impure and earthy limestones, it may be said in general that they lose their argillaceous and earthy character more and more as we pass from the lower to the upper formations, and correspondingly gain in calcareous matter and become more crystalline in appearance. It will be remembered that the rocks of the preceding group were still more argillaceous while the succeeding Onondaga limestone is more calcareous and crystalline. The true "Manlius waterlime" is not cut by the railroad as the beds occur at a higher level than the road-bed. They form two layers separated by about four feet of black limestone, and are found in the uppermost part of the formation ; they outcrop extensively in the hills east of the railroad between Fayetteville and Manlius. Large parts of this valuable formation are undeveloped and await the profitable employment of capital. Transportation is easy and the products are valuable for cement. Cavities in the water-lime are often found lined with the beautiful sky-blue or violet crystals of fluorite $\left(\mathrm{Ca} \mathrm{F}_{2}\right)$. Small crystals of calcite $\left(\mathrm{Ca} \mathrm{CO}_{3}\right)$ are rarely found. At the beds one-half mile north of Manlius occurs a curious form of calcareous matter, which in appearance and structure resembles flint only it is much softer; it occurs in nodules or bands in marly or shaly rocks. In texture it resembles the Solenhofen Lithographic stone and is striated with delicate lines showing concretionary origin; it almost entirely dissolves in hydrochloric acid. All the rocks of this group effervesce briskly with acid but are only partially soluble on account of the argillaceous matter they contain. The rocks near the lime-kiln before alluded to show stratification cleavage much less than in other cuts north or south, and appear more firm and durable; in the other cuts the rocks easily break up in thin layers, often separated by more or less earthy matter.

4. In the beds nearest Manlius a few fossils were found yet as a rule fossil remains are not common; those found in the beds consist of a few fragments of Brachiopods (Leptocoelia imbricata) Coral and plants. Tentaculites, which usually characterizes some of the rocks of this period does not seem to occur here, yet they are found in Onondaga County farther west.

5. The limestones are used to quite an extent for fencing, the thin flat fragments lying evenly and firmly in walls without the aid of cement. To a limited extent the thicker blocks, more compact in structure, are used for rough building purposes, as for foundations and the like. The upper beds before alluded to being hydraulic, or containing argillaceous matter, burn to water-lime, so called because it will harden in presence of water; it is consequently useful for cement to be used for building purposes where there is exposure to the action of water. Large quantities are burned near Manlius and shipped from the station. Quick-lime is also burned from some of the limestone of this formation.

\section{c. CORNIFEROUS (ONONDAGA LIMESTONE.)}

1. Just north of Manlius station and about one-fourth of a mile south, nearly opposite St. John's School, are beds of limestone contain- 
Ing much less argillaceous matter than the Helderberg lime rocks as shown by their more complete solubility in acid. They are of a dark gray color, and though not as light as the Onondaga limestones usually are, they nevertheless show by their fossil remains and structure that they belong to this group. The cut north of Manlius is 100 feet long and about 12 feet deep. Opposite St. John's School are two cuts each 270 feet long and from 6 to 8 feet deep, separated by an interruption of 400 feet

2. Rocks of this formation are found abundantly at the Indian Reservation quarries south of Syracuse, at Jamesville, (Green Pond and elsewhere), at Chittenango Falls (upper strata), and near Munnsville (N. Y. and O. M. R. R.) These localities are not far from an east and west line crossing Onondaga and Madison counties hear their centre.

3. The rocks are dark gray, semi-crystalline limestones almost entirely soluble in hydrochloric acid. They are compact and free from the shaly structure so frequent in the rocks of the preceeding group.

4. Some fossil remains may be found in the rocks of this group; large irregular Favosites (honey-comb coral), Cyathyphylloid coral, fragments of the stems of Crinoids, and imperfect Brachiopods are the principal forms in the cuts, yet fossils are neither as common nor as perfect as at either Jamesville or Chittenango Falls.

5. The beds on the immediate line of railroad are not utilized at present, yet at various parts of Onondaga County they are quarried extensively for lime and for the valuable building stone they furnish. The gray limestone is used quite extensively for entire buildings of which the University, the Onondaga County Saving's Bank, and the new Catholic Cathedral in syracuse, are fine exampies. It is also used quite commonly with red brick for trimmings, and to some extent for monumental work, of which fine specimens may be seen in Oakwood Cemetery. This rock has the peculiarity of becoming black when polished, even when the uncut stone is of a light gray color. It burns to a pure white lime.

\section{HAMILTON GROUP.}

1. The rocks of the Hamilton period are separated into three wellmarked groups all of which are represented on the line of the road. The groups receive distinctive names as follows:-(a) Marcellus shale, so ealled from Marcellus, Onondaga County, N. Y., where it appears in considerable quantities; (b) The Hamilton proper from the outerops in the hills near Hamilton, Madison County; and (c) The Genesee shale named from the Genesee River, where it prominently appears. The Tully limestone, intermediate between the last two, occurs in a small part of the area occupied by the Hamilton formation, but is not generally distributed.

2. a. Marcellus Shale.-About two miles south of Oran is found a cut in the Marcellus shale about 500 feet long and from 25 to 30 feet deep. At the western entrance of the tunnel the Marcellus appears to some extent though here it seems to blend and lose itself in the rocks of the Hamilton proper. A little to the southwest of the tunnel is a ravine, wholly below the level of the tunnel, cut in the same shale as deep as 60 feet. The shale here is more bituminous than that above or in the cut first mentioned. Septaria of large size are found in the bed of the steam.

b. Hamilton proper.-The rocks of the Hamilton formation proper are found only at the tunnel west of Cazenovia Lake. This structure is about 1600 feet long: with a rock cut at the western approach of 560 feet, and at the eastern of 630 feet, making a total length of nearly 2800 feet. The rock beds at the western entrance are cut through 29 feet in depth and at the eastern 35 feet. From the elevation of the land forming the hill through which the tumnel extends, and from the general thickness of the drift deposit in the immediate vicinity, it would appear that the rock not far from the eastern entrance is 50 or 60 feet in thickness above the track. 
c. Genesee Shale.-South of Georgetown are three or four shallow euts through the Genesee shale or more properly a transition rock intermediate between the Hamilton proper and the Genesee; one of the cuts is about 500 feet in length and from 5 to 10 feet deep, the others are about 100 feet each in length and somewhat deeper. True beds of the Genesee shale are eut by the railroad about one and a half miles north of Earlville. A small creek had already cut its channel some 40 feet deep before the railroad was built; the railroad follows quite closely the course of this stream though some 15 or 20 feet above it, and crosses it twice at its short bends. The roek cut is about 2000 feet long and varies from 15 to 25 feet in depth above the track.

3. a. Outcrops of the Marcellus Shale are found at Mareellus, at various points on the highway between Cazenovia and Oran, on the Chittenango creek from one to two miles north of Cazenovia, and in various ravines in both counties. $b$. The Hamilton proper occurs at places a little farther south; on the shores of Skaneatles Lake, at Vesper, various points in the town of La Fayette, at Pratt's Falls in Pompey, Delphi, New Woodstock, near Morrisville, both north and south of the village, and in and about Hamilton. c. The Tully Limestone, a member of this formation not represented on the line of the railroad, occurs near Tully, De Ruyter, and south of New Woodstock. It is also found south of Delphi in the town of Fabius. $d$. The Genesee Shale is found to a limited extent in the towns of Lebanon and Georgetown, where the formation bends northward from its east and west course across the state. Southward in Chenango and Cortland counties it occurs more commonly.

4. The rocks of the Hamilton period are shales with admixtures of impure and imperfect limestones. The lowest and uppermost strata are more fragile than the intermediate rocks, and break up on exposure to the elements into fine fragments. The Marcellus shales vary in color from dark gray to intensely black, the color varying with the amount of bituminous matter present. Much of the rock becomes a light drab on exposure to the air. Concretions are common often forming around fossils notably Orthoceras constrictum. This shale, as well as the Genesee, often resembles bituminous coal so strongly as to be mistaken for it and eapital has been foolishly expended in mining it. In the construction of the railroad between Canastota and Cazenovia this formation was crossed and a highly bituminous layer was exposed to view. Coal was immediately announced, but it was soon found to be valueless. Black shales occur in all formations and are quite likely to deceive the unenlightened; they often contain sufficient bituminous matter to blaze when ignited by a hot fire, which fact makes the shale still more deceptive, This bituminous matter is derived in a manner entirely analagous to the formation of true coal, from the partial decomposition of animals or plants, or likely both, that existed at the time the rocks were formed. Although much money has heretofore been expended in the search for coal in New York State, a knowledge of geology will show that such expenditure is useless for true coal cannot be found earlier than the Carboniferous which is nowhere represented in our state. The rocks of the Hamilton formation proper are harder, have less cleavage, and withstand more thoroughly the action of air and water. They contain traces of iron pyrites $\left(\mathrm{Fe} \mathrm{S}_{2}\right.$ ) and incrustations may frequently be found at the tunnel; fossils also occur with the same material accumulated around them, and nodules are occasionally found. Frequently masses of limestone are found in the Hamilton beds, though not to any such extent as to regard the rocks of this locality as calcareous. Farther south, howeve̊r, larger masses occur in both Onondaga and Madison counties; at Tully village this Tully limestone is burned for lime. The black shales of the Genesee as seen at Earlville contain much more bituminous matter than any other members of the group, and are quite fragile, yet do not show such remarkable horizontal cleavage as the Marcellus shale. All the rocks of the Hamilton period, and very notably those of the 
last two groups, show what is known in geology as jointed structure. Joints are planes of fracture cutting directly across the stratification; the planes sometimes occur only a few inches from each other, and are as often separated by as many feet. When the rock is removed from one side of the joint, bold faces of rock are left on the other side cut as smoothly as with a workman's chisel. Fine examples may be seen at both approaches of the tunnel and at the cut north of Earlville, where, for some distance, the track extends parallel with the planes of the joints.

5. Life was very abundant during the Hamilton period, and fossil remains are common in all the groups. The leading forms are Brachiopods, lamellibranchs, and Trilobites and a few Cephalopods and Radiates. Plants are found quite frequently though of a low order. The most common are in the form of narrow, flattened stems often branching, but with no trace of foliage, Portions of many of these stems are now represented only by a line of ferruginous matter, as it is a property of vegetable matter to collect and accumulate iron to itself. Sufficient however retain their original structure to show that they were once members of the vegetable kingdom. In the beds west of the tunnel is found a great abundance of conical, fusiform, or oval masses often presenting a scaly appearance, often with an axis of a lighter color, or red from ferruginous deposits. Some are possibly mineral concretions but most are probably some low form of plant life, perhaps stems of Lycopodiaceæ, or their allies. Animal remains especially those of Mollusca may occur in three different forms: (1.) The shell itself more or less transformed in structure or distorted in shape; (2.) The molds of the exterior; and (3.) The shell being gone, the cast of the matter composing the interior. The first two of course resemble each other; the last is often so different in appearance as to be mistaken for an entirely distinct species. The shell structure quite often retains its original appearance, though the calcareous matter composing it is often metamorphosed into calcite. The exterior crust of Trilobites is frequently found, yet is probably very much darker colored than was the original, possibly from the proximity to bituminous matter. The rock retains finely the delicate markings of the Mollusca and the surface punctations in the crust of Trilobites and the facets of their compound eyes are often wonderfully preserved. Fossils are often changed in shape and appearance by pressure, and frequently two specimens of the same shell, differently compressed, are mistaken for distinct species. Orthoceras constrictum is the most common species of the Marcellus shale and is sometimes found with the delicate Bryozoan, Aulopora training around the shell. Homalonotus Dekayi, Dalmanites calliteles and various Brachiopoda characterize the Hamilton proper and Genesee. The rock beds at the tunnel and near Earlville contain abundant fossil remains and will well repay a careful search.

6. Economical products of the Hamilton are few and of comparatively little importance. The Marcellus shale is frequently used in place of gravel for walks and drives; the more substantial rocks of the Hamilton proper are used for foundation walls of outbuildings, for fencing and, formerly, to' a limited extent for building; the Tully Limestone before alluded to is sometimes burned for lime.

\section{E. DRIFT.}

1. By drift is meant the usual superficial deposits everywhere covering the rocks and underlying the soil, not including the alluvium of rivers and smaller streams. The character of the drift varies with the geological locality as it is derived from the wearing away of rock formations. Passing from Syracuse to Earlville one will notice a marked difference in the character of boulders along the line of the road, especially those in situ in the cuts. While the pebbles and cobble-stones may be somewhat similar at all points of the road consisting of rounded fragments of sandstone, shale, limestone, and various crystalline rocks 
like gneiss, granite, syenyte, and the like,-the larger boulders will be found to vary in character as we bass from north to south. About one-fourth of a mile south of Fayetteville are found boulders of hard gypsiferous shales; from Manlius to Oran and heyond are boulders of various forms of limestone either hychaulic in character or containing such fossils as Favosites; from Cazenovia tó Earlville the limestone boulders are present but smaller and less frequent, while boulders of Hamilton shale take their place. Large boulders of crystalline rock are occasionally found at various points, some even weighing several tons. In some places the drift is cut throngh to the depth of from 40 to 60 feet without reaching rock beds, as at the "scott cut" south of Cazenovia and the "Day cut" near Lebanon. In other parts the surface formations do not exceed a foot in depth above the rock as may be seen in some of the cuts through the limestone from Fayetteville to Manlius. The following table will indicate the depth of the superficial deposits at the various cuts:

LOCALITY.

DEPTH OF DRIFT.

South of Manlius Centre,............

"، " "

One-fourth mile S. of Fayettevile..... One inile s. of Fayetteville (lime kiln) :3-4 One, one-fourth m. S. of Fayetteville_2-4 One-fourth m. N. of Manlius .......... 3-5 Just north of Manlius . . . . . . . . . . . 4 One-fourth m. S. of Manlius ......... " 6 " " " " Two m. S. of Oran .................... West entrance of Tunnel ............ East " " " ...........6-12 " South of Georgetown ............... $3-8$ One and one-half m. N. of Earlville_.2-9

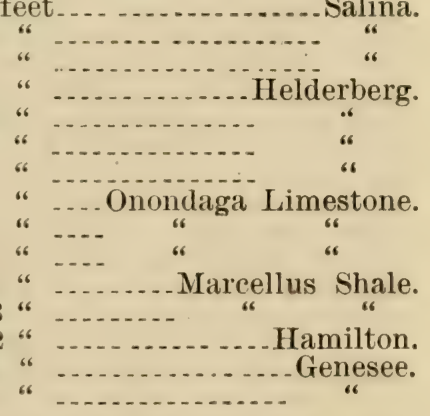

In some places as at Manlius (opposite St. John's School) and on the shores of Cazenovia Lake are found smooth, polished surfaces of rock, and fine parallel striæe and grooves indicative of glacial action. In the cut just north of Fayetteville and near the junction with the U. I. and E. R. R., may be seen boulders of black limestone which also present polished and striated surfaces.

2. It is evident that the drift deposits, at least the boulders, have been derived from the north. No prominent beds of crystalline rocks are found south of the middle line of New York State, consequently the scattered boulders of gneiss and svenyte are derived from beds of like formation in the northern part of the state. On the line of the road in question it will be noticed that the boulders of gypsiferous shale are found south of Fayetteville, while like beds in position are found north of that place; that limestone boulders are common south of Manlius and Oran and become less frequent south of Cazenovia, while the limestone rocks in place (Helderberg and (Onondaga) are near Manlius or farther north; and that boulders like the II amilton shales in appearance, structure, and fossil remains, are foumd abundantly south of the first Hamilton beds between Oran and Carenovia but never north of them. What is true of this line of railroad respecting the drift, is true of all parts of the counties through which it passes and for the state. Even the soil is often determined from the character of the northern rocks. The vast surface formation of red clay, crossing Madison County from Chittenango to Oneida is derived from the beds of red argillaceous iron ore of the Clinton groul), south of which and partly above which the clay formation rests. It is generally held that the origin of the drift is due to deposits from vast glaciers which formerly covered 
the state having a north and south motion, and that the polishing and striation of rocks is due to the same cause. Sufficient evidence in support of this theory may be derived from a careful study of the drift itself; and a study of existing glaciers of the Alps of switzerland and in other countries discloses similarities of action and formation that are confirmatory and convineing.

3. The natural products of any region are important data as a key to the economic and agricultural geology of a country, so that botany becomes allied inseparably with geology. As the number and variety of fresh water Mollusca (univalve and bivalve) are a measure of the calcareous quality of the water of any region they also become an important factor in geology, and zoology comes into alliance with geology. In fact, the three sciences are so closely related, that no one can acquire the least degree of thoroughness and proficiency in geology, without being thoroughly conversant with both the others. One would naturally expect little variety in the vegetable products in so short a space as fortythree miles, the length of the road; yet the change, especially in trees and woody plants, is quite marked. Near Syracuse the timber consists of oak, chestnut, hickory, tulip, basswood, and elm, with scarcely any hard maple or beech. While basswood and elm continue the whole length of the road, chestnut becomes rare at Manlius while hickory and oak continue to some extent to Cazenovia but no farther; maple and beech are common at Oran and form the principal timber at places farther south; hemlock, though present everywhere, is most common from Erieville to Lebanon. The large pine stumps in Erieville Reservoir and at other points along the road, indicate a former entensive growth of valuable pine which is almost extinct or, if present, is small and almost worthless.

(A list of trees and woody plants of Madison and Onondaga counties together with a partial list of land and fresh water shells will be found at the close of this article.)

4. The adaptability of the various parts of this region to different agricultural products depends largely on the distance above the sealevel combined with the character of the soil and various minor conditions. About Syracuse and in the northern portion of the counties of Onondaga and Madison where the elevation above the sea is least and the soil naturally productive wheat and other grains flourish, together with fruit of various kinds. At Cazenovia and especially farther south, at greater elevations, and often with inaccessible plow lands, grazing is a more common occupation. At Georgetown, less thickly settled in many parts, are considerable stores of lumber on the densely wooded hills.

(At the close of this article will be found tables of elevation of the stations, and statistics of farm products as these will best indicate the agricultural character of this section.)

5. The economical products of the drift along the line of the road are few and unimportant, sand being at present the only one of account, though bricks were formerly manufactured from the beds of red clay at various points.

\section{HYDROGRAPHY.}

A. 1. The northern portion of the counties under consideration is drained by streams belonging to the St. Lawrence system, the Seneca, Oneida, and Oswego rivers serving as the outlets of many minor streams, some of which are of local importance. Nine Mile Creek and Onondaga Creek both rising in the south-west corner of Onondaga County find outlet through Onondaga Lake, the former passing through Otisco Lake during its course. The chief tributaries received through Oneida Iake are Chittenango and Oneida creeks, the former receiving the waters of Butternut and Limestone creeks in Onondaga County and Canaseraga 
and Cowasalon in Madison; Oneida creek take its rise near the centre of Madison County and flows into the head of Oneida Lake. The streams of the st. Lawrence systems thus form a series of at least six well-defined valleys, nearly parallel with each other, and extending northward in their general direction.

2. The susquehamma drainage is ehiefly through the waters of its four tributaries, - the Tioughnioga, Otselic, Chenango, and Unadilla rivers. Of these only the first drains any portion of Onondaga County, and a portion of its waters are received from Madison; the Otselic and Chenango take their rise in Madison County, while the Unadila forms part of its extreme eastern boundary and receives a few small streams from the town of Brookfield. While nearly one-half of Madison County is drained by the Susquehanna, more than nine-tenths of Onondaga is drained by streams belonging to the St. Lawrence system. The streams of the susquehamna drainage form a series of at least three well marked valleys extending south from Madison County.

$B$. The general trend of the "ridge of land" is marked very nearly by a line passing in an east-north-east direction through the villages of Tully, Fabius, Erieville, Morrisville, and Munnsville. In elevation this water-shed varies from twelve hundred to sixteen hundred feet above the sea level and probably some portions rise much higher. The head waters of the two systems often occur very near to each other. One instance may be found just east of Nelson where the head waters of the Chittenango Creek and Chenango River are probably less than half a mile apart, while among the picturesque Tully lakes are two basins of considerable extent less than one-fourth of a mile apart, whose waters are widely divergent in their final destination, one passing south into the susquehamna, the other north into Lake Ontario.

C. In the northern portion of the two counties, the general surface is level and as a consequence the streams are deeper and more sluggish. Farther south, on both sides of the water shed, the streams have a more rapid current and often form cascades or waterfalls. The general effect is to erode more of the surface, cut out gulches or ravines, and expose large faces of rocks to view. Among the leading water falls are two in the town of Pompey, and those at Perryville and Chittenango Falls in Madison County. The two former, Pratt's Falls and Delphi Falls cut through the rocks of the Hamilton formation, while the two latter cut through various limestone strata of the Helderberg series especially the Water Lime, Onondaga, and Corniferous. Other falls of less importance are found in various parts of both counties among which may be mentioned those near New Woodstock, Vesper, Marcellus, Manlius, and Munnsville.

The stream near Delphi, Onondaga County, illustrates finely the two classes of water falls depending on the nature and relative position of the rocks over which the water Hows. The fall is in two distinct portions separated about thirty rods from each other; the rock strata at the upper fall are hardest at the top and softer below, consequently the rocks at the base of the falls are most worn and the water flows with a single plunge from top to bottom; at the lower fall the rock strata are rather softer at the top and harder below, consequently the rocks at the top wear away more rapidly than below, and the water instead of falling with a single plunge, flows down a succession of terraces or steps.

D. Among the largest lake basins wholly in the state is Oneida lake north of these two counties. Its longest axis has a general direction east and west, its length being about twenty-five miles and irs width about six miles. In the direction of its axis it presents a marked exception to the other lakes of the state, they for the most part having their greatest length north and south. Skaneateles Lake stands next in size bordering on the western side of Onondaga County; its axial direction conforming with the general rule for the state. Of the lakes wholly included in the counties, Onondaga Lake near Syracuse, Otisco Lake in the southwestern part of Onondaga, and Cazenovia or Owahgena 
Lake in the western part of Madison are of the most importance; all extend nearly north and south in general direction. Besides these are the romantic 'Tully Lakes, nine in all (only four however of any considerable size) on the watershed between Cortland and Onondaga counties; these also conform in axial direction with the others. In Madison County are Madison and Hatch's lakes with various others of less size and importance.

Ponds are found in considerable numbers in both counties. Among the most remarkable are the so called "Green Ponds." Of the largest and most peculiar are two near Jamesville, one among the Tully lakes, and the largest of them all near Kirkville. They are commonly considered "bottomless," but soundings in some parts of the Kirkville pond indicate a depth of 90 feet. The water in all is remarkably clear, contains much calcium carbonate $\left(\mathrm{Ca} \mathrm{CO}_{3}\right)$, and to a greater or less extent is charged with hydrogen sulphide $\left(\mathrm{H}_{2} \mathrm{~S}\right)$. 'This last feature is more noticeable at Kirkville, and the pond has received the appropriate name of Lake Sodom. Great quantities of marl are found in the immediate vicinity and in some parts the banks are wholly composed of this material. The pond one-half mile east of Jamesville is surrounded on three sides by almost perpendicular cliffs of limestone; in this pond are found considerable quantities of Chara and other aquatic plants. Many of these ponds with their surrounding territory are repositories of rare and interesting plants, and many choice species will reward the diligent search of the botanist. Among other plants may be mentioned Scolopendrium vulgare, the rase Hart's Tongue Fern, at the pond near Jamesville; Pogonia pendula at Kirkville; and Zygadenus glaucus at "Tamarack Swamp" near Syracuse, which has every appearance of a former pond now filled with moss and aquatic plants and covered with a growth of Coniferæ.

Geologically, the basin of Oneida Lake is cut in the Clinton formation, Onondaga in the Salina, and the remaining lakes in the Hamilton. Ponds are found in every formation represented in the counties from north to south.

E. The most remarkable springs in this portion of the state are the Salt Springs of Syracuse and salina too well known to be discussed here. In connection with these are the Chlorine springs charged for the most part with chlorine gas, probably derived from the decomposition of salt and other chlorides. The presence of salt on the shores of Onondaga Lake has caused many marine plants to remain and flourish, that are found elsewhere no nearer than the sea. Among these are Ranunculus Cymbalaria, Hibiscus Moscheutos, Salicornia herbacea. Chenopodium glaucum and many others. Sulphur springs are abundant and are quite generally distributed over both counties. One in particular, "The White Sulphur springs," two miles south of Chittenango has been to some extent a summer resort for invalids. In various parts of both counties springs and wells may be found containing hydrogen sulphide $(H, \mathrm{~S})$ in solution to a greater or less degree. The water of Green Lake near Kirkville, before alluded to, is sufficiently charged to give a perceptible taste of sulphur. Chalybeate or iron springs of various kinds are found in Madison Comnty in various localities; none, however, are important.

F. The streams in all parts of Madison and Onondaga Counties as well as in all parts of New York State, contain far less water than formerly. Many streams in various parts which formerly were sufficiently large to furnish mill-power throughout the year are now nearly dry during the heat of summer and only of their former size during floods. On the larger streams, where there was formerly much maufacturing interest and numerous factories and mills of considerable importance, there are now scarcely any. Although a part of this decrease in manufacture may justly be attributed to the centralization of capital in larger establishments with the consequent advantages of improved machinery, still very much is due to the deficiency of water 
power as well as a lack of uniformity in its supply. It is a well known fact that the clearing of forests diminishes to a like degree the supply of water in streams of all sizes. The forests must be sared or stean must eventually take the place of water power, and railroads the place of river navigation, while agriculture must correspondingly suffer from lack of frequent and uniform rains.

\section{VALLEY FORMATIONS.}

A. It is remarkable that nearly all the valleys of the counties of Onondaga and Madison extend north and south, the only marked exception being the basin of Oneida Lake, which has its axis at right angles with this usual direction. Skaneateles Lake, Otisco, Onondaga, and Cazenovia lakes, the Tully lakes, and others have their greatest length from north to south, and all are situated in a basin of far greater area than that now covered hy their waters. The streams of both counties for the most vart occupy deep broad valleys that extend in the same direction as the lake basins. Any one crossing the counties from east to west through their central portion would alternately cross vallevs and ridges of greater or less extent, and for a long distance the view would be unobstructed to one looking north or south, up or down the various valleys. Thus a marked uniformity is prevalent, naturally suggesting uniformity of cause in their formation. This uniformity however, is not confined to these counties.

B. Throughout the central and western portions of the State of New York the north and south axial direction for lakes and watercourses prevails to so great an extent as to be almost a geographical law. Of lake basins west, Hemlock, Conesus, Honeove, Canandaigua, Keuka, Seneca, Cayuga, and Owasco all conform to the law, while east are Schuyler's and Otsego lakes with lakes George and Champlain. Of river basins the Genesee, Oswego, Black, Tioughnioga, Chenango, Otselic, Unadilla, schoharie, and Hudson rivers, with innumerable smaller streams all extend nearly north and south. Some streams like the Mohawk and Seneca rivers present an axial direction at right angles with the usual one as is also true of a few of the smailer lakes. Looking beyond our own state it will be observed that the greater number of the rivers of New England, Ohio and other states nortl of $40^{\circ} \mathrm{N}$. Latitude conform to the same law as the rivers of New York. Lakes Huron and Michigan have their longest axis extending north and south while Superior, Erie, and Ontario extend east and west.

What means this marked uniformity? Similar geological formations generally indicate similarity in the causes and forces producing them, and often contemporaneity of formation. It is only acting in accordance with the old law that "Like causes produce like effects," which, if applicable anywhere must apply to the formation of so many parallel valleys.

C. There is every reason to believe that most or all of the lakes of New York formerly stood at a much higher level than at present. In "sketches of Creation," Chap. XXII, Winchell has given the evidence supporting the theory of the former higher level of the great lakes. There seems as clear evidence of a similar, though less extensive, elevation of the lakes of smaller size.

The evidence briefly summed up is as follows:

(a) The rainfall was formerly greater, consequently the quantity of water in the streams contributing to the supply of these lakes was much larger than at present.

(b) The low land bordering on the shores of the lakes gives evidence in lacustrine deposits, fresh water shells, and general appearance of the former presence of fresh water.

(c) The topography of the land in the immediate vicinity of the 
lakes indicates that a great elevation would be possible, and that even a slight elevation would cause the inundation of a large extent of territory.

(d) The topography of the outlets is such that the supposition of former elevation would cause no inconsistency in this direction. There ave even indications of former barriers now broken away which must have raised the level of the lakes when they were in existence.

From these reasons, which might be easily extended and particularized, there is abundant evidence for supposing that most, if not all, of the lakes of this region formerly occupied more surface and possessed much greater depth than at present. The absence of topographical maps of this portion of the state has covered the fact that a comparatively slight elevation of water would cover a vastly greater area than the lakes now occupy. It is not improbable that some of these lake basins were once connected with each other.

It may not be unprofitable to speculate concerning the future of some of these lakes, knowing that in the past they covered greater areas. The operations of nature going on before our eyes are tending to decrease the depth and superficial area of all the smaller lakes. The lacustrine deposits in the lake bottoms are constantly increasing, and where the water is shallow, aquatic plants are encroaching each year on the lake margins and are building up land where formerly water existed. Carpenter's Pond in the town of Pompey illustrates finely the method that nature employs in filling up her water basins. The pond is situated in the midst of a large swamp, which was once wholly covered with water. Around the margin of the pond is a border of grass and aquatic plants from one to eight rods wide which has encroached on the shores of the pond even where the water is of considerable depth. This surface of turf overlying, as it does, the deep water of the pond will tremble and shake as one walks across it; in time it becomes more firm and is ready for the encroachment of shrubs and forest trees which soon follows that of the weaker plants. Not many generations hence the turf will cover the entire surface and Carpenter's Pond will be known only by tradition. A similar formation may be seen near Pecksport, Madison County, where there are two ponds, one of which has become entirely overgrown with aquatic plants and moss. 'This pond has received the fanciful name of "Fiddler's Green." In like manner we may expect that all our inland lakes will become extinct, though it may be generations hence that the inevitable result will be accomplished.

D. A review of the existing glacial regions of the world and the evidence derived from former glacial regions like Scotland and Sweden that have been most thoroughly and carefully studied and mapped, seems to indicate the explanation of so many parallel valleys in our own country. By consulting Geikie's maps of the glacial regions of Scotland and Sweden it will be seen that the direction of the glacier flow and of the present river and lake valleys almost exactly coincides. That glaciers deepen and widen channels and valleys may be inferred from a knowledge of their nature and action, and the inference entirely accords with observations among the Alpine glaciers. Fiords, the deep narrow inlets cut in the northern coasts in high latitudes, are considered due to glacial action, and the same agency that would erode a fiord would erode a valley in a similar way.

$\Lambda$ ll our valleys show more or less glacial action in the form of rock polishing and striating, as well as in the arrangement of the drift between parallel ridges. It is probable that, as there are two series of valleys, one having an axial direction in general north and south and the other east and west, there were also two series of glaciers traversing the state in these two directions. Evidence, at present, is not sufticient to demonstrate which one was earlier yet certain indications seem to point to the one with the north and south motion as the later. Further evidence must be accumulated, the drift must be more carefully studied, 
the rock-surfaces must be more thoroughly searched for striæe and other evidences of glacial action, before any satisfactory generalization can be reached; still the general features of the land and the resemblances to known glacial action and phenomena are so striking that they unmistakably point to glaciers as the primal cause of valley formations in our state.

\section{TABLES AND LISTS.}

A. Elevation, distances, and geological formations of the various stations on the S. and C. V.R. R.

\begin{tabular}{|c|c|c|c|c|c|}
\hline \multirow{2}{*}{ STATIONS. } & \multicolumn{2}{|c|}{ DISTANCES. } & \multirow{2}{*}{$\begin{array}{c}\text { Elevation } \\
\text { above } \\
\text { tide water }\end{array}$} & \multicolumn{2}{|c|}{ GEOLOGICAL FORMATION. } \\
\hline & $\underset{\text { Syracuse. }}{\text { From }}$ & $\begin{array}{l}\text { Between } \\
\text { Stations, }\end{array}$ & & North of Station. & South of Station, \\
\hline $\mathrm{yr}$ & 0 & 0 & $395 \mathrm{ft}$. & Sal & Sali \\
\hline Manal & $6.7 \mathrm{~m}$. & $6.7 \mathrm{~m}$. & $520 “$ & s: & *S \\
\hline $\mathrm{F}$ & $9.6^{\prime \prime}$ & 2.96 & $\tilde{0} 90$ “ & *Sa & (lerl)erg \\
\hline Manlius & $12.2^{6}$ & $2.6 “$ & 720 & *Cor & us. \\
\hline $\mathrm{O}_{1}$ & $14.6 \%$ & $2.4^{66}$ & $897 “$ & *Col & S. \\
\hline $\mathrm{Tl}_{\mathrm{S}}$ & 19.0 “ & 4.46 & $1218^{6}$ & *Ma & $* 1$ \\
\hline $\begin{array}{l}\mathrm{Ca} \\
\mathrm{W}\end{array}$ & $20.4 “ 6$ & $1.4 \%$ & $\begin{array}{ll}1190 \\
1300 ،\end{array}$ & $\begin{array}{l}\text { *Ha } \\
\text { Han }\end{array}$ & \\
\hline & 28.7 “ & $6.0 ،$ & 1596 “ & $\begin{array}{l}\text { Ha } \\
\text { Ha }\end{array}$ & Hamilton. \\
\hline & 32.3 “ & 3.64 & 1687 “ & Haur & *rienesee. \\
\hline & $37.5 \%$ & $5.2 \%$ & $1: 364$ " & *Gen & *Genesee. \\
\hline & $43.5 “$ & $6.0^{6} 6$ & 1077 & *Genesee. & Genesee. \\
\hline
\end{tabular}

* An asterisk indicates that rock cuts may be found on the line of the road in the direction from the station indicated.

B. List of Fossils collected on the line of the S. \& C. V. R. R.

LOWER HELDERBERG.

PLANTS.

One undetermined species.

BRACHOPODA.

RADIATA.

One undetermined coral.

Leptocolia imbricata.

CORNIFEROUS (ONONDAGA LIMESTONE).

Favosites sp. RADIATA.

A ulopora $s p$.
BRACHIOPODA.

Discina minuta.

Zaphrentis Rafinesquii.

\section{MARCELLUS SHAlE.}

\begin{tabular}{l|l}
\multicolumn{2}{c|}{ BRYOZOA. } \\
$\begin{array}{l}\text { Aulopora sp. } \\
\text { BRACHIOPODA. }\end{array}$ \\
$\begin{array}{c}\text { Leiorhynchus dubius. } \\
\text { Discina minuta. }\end{array}$ & $\begin{array}{c}\text { Coniatites Marcellensis. } \\
\text { Orthoceras constrictum. }\end{array}$
\end{tabular}

HAMILTON (PROPER).

PLANTS.

Four undescribed species.

Tentaculites $s p$.

RADIATA.

One undetermined crinoid.

Four undetermined corals. BRYOZOA.

One undescribed species. BRACHIOPODA.

A mbocalia umbonata.
Leionhynchus multicosta.

Lingula sp.

Rhynchonella prolifica.

R. sappho.

: pirifer granulifera.

s. medialis.

S. $s p$.

S. $8 p$.

Spirigera concentrica.

strophodonta fragilis. 
S. perplana.

Terebratula $s p$.

Tropidoleptus carinatus.

LAMELLIBRA NCHIATA.

Avicula flabella.

Grammysia bisulcata.

G. Hamiltonensis.

Microdon bellistriatus

Two undetermined species.

Platyceras carinatum.
Pleurotomaria rotalia.

$P$. sulcomarginata.

Two undetermined species.

Orthoceras exile.

CEPHALOPODA.

O. nuntium.

O. $s p$.

TRILOBITA.

Dalmanites calliteles.

Homalonotus DeKayi.

Phacops rana.

\section{GENESEE SHALE.}

Orthis $s p$.

BRACHIOPODA.

Rhynchonella contracta.

Spirifer granulifera.

S. mucronatus.

Terebratula sp.

Tropidoleptus carinatus.

LAMELLIBRA NCHIATA.
Microdon bellistriatus.

Six undetermined species.

Orthoceras $s p$. CEPIIALOPODA.

Dalmanites calliteles.

Homalonotus De Kayi.

C. List of trees and woody plants growing spontaneously in Madison and Onondaga counties.

* Abies Canadensis, Micha.

Acer Pennsylvanicum, $L$. Cazenovia Lake.

*A. rubrum, $L$.

*A. saccharinum, Wang.

A. spicatum, Lam.

Alnus incana, Willà.

Amelanchier Canadensis, Torr. \& Gr. Ampelopsis quinquefolia, Michx.

Azalea nudiflora, $L$. Syracuse, Hamilton.

Berberis vulgaris, $L$.

* Betula lenta, L.

*B. lutea, Mich $x, f$.

*Carpinus Americana, Michx.

* Carya alba, Nutt.

*C. amara, Nutt.

*C. microcarpa, Nutt.

* Castanea vesca, $L$.

*Celastrus scandens, $L$.

Cephalanthus occidentalis, $L$.

Cornus alternifolia, $L$.

C. circinata, L'Her.

*C. florida, $L$. Syracuse, Chittenango.

C. paniculata, L'Her.

C. servea, $\bar{L}$.

C. stolonifera, Michx.

Corylus rostrata, Ait.

Cratogus coccinea, $L$.

C. Crus-galli. $L$.

C. tomentosa, L., var. punctata.

Dirca palustris, $L$.

* Fagus ferruginea, Ait.

* Fraxinus Americana, $L$.

* F. pubescens, $L$.

* F. sambucifolia, Lam.
Hamamelis Virginica, $L$.

Ilex lcevigata, Gray, Tully.

* Juglans cinerea, $L$.

*J. nigra, $L$.

* Larix Americana, Michx.

*Liriodendron Tulipifera, L. Syracuse.

Lindera benzoin, Meisner.

* Magnolia acuminata, L. Elbridge.

Myrica cerifera, $L$.

M. gale, $L$.

Nyssa multiflora, Wang. Syracuse.

* Ostrya Virginica, Willd.

* Pinus rigida, $L$.

*P. strobus, $L$.

* Populus balsamifera, $L$.

*P. grandidentata, Michx.

*P. tremuloides, Michx.

* Prunus Pennsylvanica, $L$.

*P. serotina, $L$.

$P$. spinosa, $L$.

$P$. Virginiana, $L$.

Pyrus Americana, DC.

$P$. arbutifolia, $L$.

$P$. coronaria, $L$.

*Quercus alba, L.

*Q. coccinea, Wang.

*Q. macrocarpa, Nutt. Syracuse.

*Q. prinus, L. var. acuminata, Michx. syracuse.

*Q. rubra, $L$.

Rhus glabra, $L$.

$R$. Toxicodendron, $L$.

$R$. typhina, $L$.

$R$. venenata, $L$.

* Salix alba, L.

S. candida, Willd. 
S. cordata, Muhl. var. angustata.

S. discolor, Muhl.

S. fragilis, $L$.

S. humilis, Karshall.

S. livida Wahl. var. occidentalis.

S. lucida, Muhl.

s. nigra, Marsh.

S. sericea, Marshall.

S. tristis, Ait,

var. microphylla. Carpenter's Pond.

S. viminalis, $L$.

Sambucus Canadensis, $L$.

S. pubens, Michx.

* Sassafras officinale. Nees.

Staphylea trifolia, $L$.
Taxus baciata, L. var. Canadensis.

* Thuja occidentalis, $L$.

* Tilia Americana, L.

*Ulmus Americana, $L$.

*U. fulva, Michx.

*U. racemosa, $L$.

Vaccinium corymbosum, $L$.

Viburnum acerifolizum, $L$.

$V$. dentatum, $L$.

$V$. lantanoides, Michx.

$V$. Lentago, $L$.

$\checkmark$ Opulus, $L$.

Vitis cestivalis, Michx.

$V$, cordifolia, Michx.

V. Labrusea, $L$.

Zanthoxylum Americarum, Mill.

* Those marked with an asterisk are large forest trees.

In case of a few rare species the locality is given.

D. Partial list of land and fresh water Mollusca from the counties of Onondaga and Madison.

\section{FAMILY UNIONID压.}

Unio complanatus, Solander, Onondaga Lake.

$U$. luteolus, Onondaga Lake.

Anodonta excurvata, Carpenter's Pond.

A. plana, Lea, Cazenovia Lake.

Margaritana marginata, Say, Oneida Lake.

\section{FAMILY HELICID赵.}

Mesodon albolabris, Say, Cazenovia.

$M$. thyroides, Say, Cazenovia.

Sterotrema monodon, Rackett, Cazenovia.

Triodopsis tridentata, Say, Manlius.

$T$ palliata, Say, Manlius.

Patula alternata, Say, Manlius.

\section{FAMILY ARIONIDE.}

Omphalina lavigata, Pfeiffer, Cazenovia.

\section{FAMILY LININAID}

Helisoma trivolvis, Say, Onondaga Lake.

Planorbella campanulata, Chenu, Cazenovia Lake.

E. Agricultural Statisties of the counties of Onondaga and Madison (compiled from state census, 1875.)

\section{FARMS.}

\begin{tabular}{|c|c|c|}
\hline & Onondaga, & Madison. \\
\hline Acres impro & 373,516 & 301,916 \\
\hline roved ( & 54 & 21,764 \\
\hline " & 25, & 68,610 \\
\hline Number of $\mathrm{fa}$ & 5,001 & 4,639 \\
\hline Cash value of farms.. & $\$ 37,251,541$ & $\$ 24,057,102$ \\
\hline
\end{tabular}


2. PRODUCTS OF CULTIVATION.

\begin{tabular}{|c|c|c|c|c|c|c|c|}
\hline \multirow[b]{2}{*}{ Leading Products, } & \multicolumn{3}{|c|}{ Onondaga, } & \multicolumn{3}{|c|}{ Madison. } & \multirow{2}{*}{$\begin{array}{c}\text { Avg. } \\
\text { yield } \\
\text { for } \\
\text { state. }\end{array}$} \\
\hline & Acres. & Bushels. & $\begin{array}{l}\text { Avg. } \\
\text { Yield. }\end{array}$ & Acres. & Bush. & $\begin{array}{l}\text { Avg. } \\
\text { Yield. }\end{array}$ & \\
\hline Jin & $\overline{28,604}$ & 528,760 & 18.49 & $\overline{6,380}$ & $\overline{104}$ & 16.43 & $\overline{16.16}$ \\
\hline Corl & 24,921 & 894,723 & 35.90 & 10,213 & 326 & 31.96 & 32.33 \\
\hline & 40,663 & $1,319,958$ & 32.46 & 26,414 & 847 & 32.08 & 28.59 \\
\hline & 967 & 13,482 & 13.94 & 338 & 3,986 & 11.79 & 11.82 \\
\hline $\mathrm{Ba}$ & 10,395 & 261,215 & 25.13 & 2,833 & 72,039 & 25.43 & 22.83 \\
\hline eat & 4,109 & 65,935 & 16.05 & 1,863 & 29,302 & 15.95 & 15.14 \\
\hline & 9,286 & $1,096,409$ & 118.07 & 4,741 & 581,634 & 122.68 & 10222 \\
\hline$t$ & 98,554 & $132,281^{*}$ & $1.34 *$ & $\| 100,247$ & $|129,319|$ & $1.29 *$ & $1.13 *$ \\
\hline
\end{tabular}

*Tons.

\section{LIVE STOCK.}

\begin{tabular}{|c|c|c|}
\hline 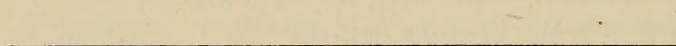 & Onondaga. & Madison. \\
\hline Cattle of all grades & 53,672 & 54,158 \\
\hline Horses..... & 17,405 & 11,731 \\
\hline Mules....... & 234 & 134 \\
\hline Sheep a & 64,040 & 27,554 \\
\hline Swine ... & 31,499 & 15,428 \\
\hline
\end{tabular}




\section{QE 146.M3 U 53 Cork Botanical Garden Library}

Underwood L C.2

Jilrood, Lucien M/The geological form gen

35185001238060 
